Kaplan, Martha (2018): Dilemmas of Belonging in Fiji, Part I: Constitutions, Coups, and IndoFijian Citizenship. In: Elfriede Hermann and Antonie Fuhse (eds.): India Beyond India: Dilemmas of Belonging. Göttingen: Göttingen University Press (Göttingen Series in Social and Cultural Anthropology, 12), pp. 83-98. Doi: 10.17875/gup2020-1265

\title{
5 Dilemmas of Belonging in Fiji, Part I: Constitutions, Coups, and Indo-Fijian Citizenship
}

\author{
Martha Kaplan
}

\section{Introduction: Towards a Historical Anthropology of Dilemmas}

Postcolonial nation-states and democratic electoral systems were meant to enable self-determination. Yet they have not resolved dilemmas of belonging. The Indo-Fijians, descendants of Indians who came to Fiji in the $19^{\text {th }}$ century labor diaspora, are currently a minority in the nation-state which they share with ethnic Fijians, descendants of Pacific Islanders resident in the islands. This chapter describes the twentieth century history of how Indo-Fijian anticolonial spokesmen fought for independent Fiji and national belonging with a focus on 'common roll' electoral rights. But Fiji's constitution at independence in 1970 was unusual for its continuation of implacable colonial race categories, its refusal of common roll, and its weighting against IndoFijian political representation. And then, a series of coups were mounted by ethnic Fijian military leaders, not Indo-Fijians. Many Indo-Fijians have chosen emigration when possible, seeking self-determination by diaspora. Soberly, this chapter considers the history of plans for Fiji's democracy embodied in constitutions, elections and other political rituals since 1970, the prospects for self-determination via democracy in Fiji, and the conditions for national belonging for people of Indian descent in Fiji.

In the twentieth century and into the twenty-first, across the globe, people have faced a common global situation: utopian hopes of the self-determining nation-state, within a post-World War II framework of states and institutions as the way out of 
colonial domination, have been unsettled by "failure of the nation to come to its own" (Guha 1988: 43), by global dynamics pushing and pulling at the framework itself (Appadurai 1996), and by realizations of diverse potentials of democratic institutions in practice (Tambiah 1996). Insistence on the contradictions inherent in social orders of Marxist social theory might suggest a set of inevitable crises provoking new stages. But the kinds of contradictions of social systems, and their outcomes in peoples' lives, are far from predictable. If we take seriously the egalitarian premises that anticolonial activists fought for, an anthropology of dilemmas leads us to sober consideration of what variously and less predictably may happen when egalitarian possibilities of democracy run into, or even generate, inequalities, especially in social fields rife with colonial insistence on racial otherness (Kelly and Kaplan 2001a, 2001c). Scholarly thinking about dilemmas of belonging in the Indian diaspora generally begin with India - dilemmas of leaving heritage connections behind. But here, let us focus on the other side of the coin: Belonging to what? Looking forward to what?

Let us consider new ways to respect the history of anticolonial nationalist visions, especially Gandhian explorations of independence and interdependence, while we also understand the often disappointing outcomes. These are not new challenges for political and historical anthropology. ${ }^{1}$ Anthropology complicated the proposal that cultural orders are unchanging templates for individual experience when Ruth Benedict discussed dilemmas of virtue in her 1946 Chrysanthemum and the Sword. Indeed, Benedict considered both individuals and the transformations of a sweep of Japanese political history in relation to dilemmas that are experienced individually, but culturally oriented, culturally distinctive but highly dynamic. Stanley Tambiah, scholar of dialectical tensions in the sweep of Asian histories, brings a similar focus on systemic possibilities in postcolonial states. In his 1996 Leveling Crowds, he considers the dilemmas of democracies and draws our attention to the phenomenon of leveling, in which - under certain conditions - members of actual or potential electoral majorities nonetheless seek to dispossess others of rights or privileges, real or imagined.

This chapter provides a brief overview of Fiji's wider multi-ethnic colonial history, and then considers national belonging through focus on three historical periods of Indo-Fijian experience of citizenship and democracy. First, in the colonial and decolonizing era up to 1970, Indo-Fijians were at the forefront of Fijis anti-colonial struggles. Indentured sugar cane workers and free immigrants to Fiji looked to Gandhian leadership and tactics to challenge the British and work for 'common roll' electoral self-representation. Simultaneously, in the constituting of citizenship, longterm colonial racism deliberately set the stage for uneven belonging through citizenship in independent Fiji.

\footnotetext{
${ }^{1}$ Dilemmas of social and policy sciences more broadly have also been considered insightfully, see Rittel and Webber (1973), who in the 1970s discussed challenges facing social planners along dimensions of goal formation, problem definition, and consideration of equity and justice.
} 
Second, from independence in 1970 until 2006, democratic electoral possibilities were shaped and skewed by colonial 'race' categories. 1970 Independence images of a 'three-legged stool' envisioned national leadership by ethnic Fijian chiefly elites and interdependence of ethnic Fijian commoner landowners (83\% of Fiji's land is owned by descendants of indigenes), with Indo-Fijians as economic backbone of the sugar industry, and the British crown as guarantor of the parliamentary system. But at independence, to participate as national citizens, Fiji's citizens had to identify themselves 'racially' (as the colonial British termed it) for 'communal' (i.e. not 'common') voting rolls, as 'Fijians,' 'Indians, or 'General Electors.' The complexities of ethnic Fijian and Indo-Fijian visions of belonging were channeled into a particularly persistent and unequal set of racist and 'race' categories. Thus colonial contradictions pervaded the post-colonial belonging, creating a political climate in which multiple Fijian ethnonationalist coups took place. In a hopeful moment in 1997, led by a historically and globally aware constitutional commission, Fiji citizens, including Fiji's Indo-Fijians (by then under $44 \%$ of the population), contributed to the design of a new electoral system that was meant both to acknowledge historical community ties and to lead to a common feeling of belonging as citizens. But in 2000, another coup toppled the multi-ethnic government elected under the 1997 constitution. In 2006, the leader of Fiji's military seized power and abrogated the constitution.

Third, thus, in 2013 common roll was instituted, but by a military government. To be clear, this coup was neither led by, nor on behalf of, Indo-Fijians. Nor is the current regime explicitly Fijian ethnonationalist (although the military forces and leadership are still overwhelmingly ethnic Fijian). Instead, it came to power in a military coup similar to other military coups across the globe, in which the goals of military rule supplant other political stances. The regime propounded a modernizing, 'anti-corruption' message and imposed military rule, claiming provocation, as colonial governments did, by 'disorder and disaffection.' This chapter will thus end with questions, rather than conclusions, about the potential for national belonging in Fiji. ${ }^{2}$

\footnotetext{
2 This chapter draws upon previous publications, many co-authored with John D. Kelly (e.g. Kelly and Kaplan 1999, 2001b, 2001c, 2004, 2007, and Kaplan and Kelly 1994, 1999, 2017). While my historical and contemporary research initially focused only on anticolonial and postcolonial ethnic Fijian experience (Kaplan 1995, 2007, 2011), collaboration with John D. Kelly has shaped my appreciation of the relation of the Indo-Fijian experience to global South Asian and decolonizing culture and history. Touchstones for the understanding of these histories are the works of Bernard Cohn (1987, 1996, 2002 (with Teri Silvio), 2013) and Stanley Tambiah (1996). Brij V. Lal (1983, 1988, 1992, [1997] 2011a, $2011 \mathrm{~b}$ ) is the author of a body of foundational political histories of Fiji which focus on Indo-Fijian experience. The work of Marshall Sahlins $(1978,1985,2005)$ is crucial for an understanding of longue durée ethnic Fijian history and history-making.
} 


\section{Narratives of Fijian Colonial History}

The colonial experience was very different for Pacific Islander descended peoples and for Indian descended people in Fiji. ${ }^{3}$ Fijians resident in the islands when Europeans arrived in the late 1700s were organized in competing local kingdoms in the coastal and island areas, especially the largest island, Viti Levu, and in less hierarchical polities in the interior. Led by King Cakobau, most Fijians converted to Christianity in 1854. In 1874, Cakobau and a group of high chiefs 'gave' the islands to Queen Victoria. This founding moment, and the document known as the Deed of Cession, can be understood in Fijian cultural terms as the installation of a king or chief, in which the leader is given rule over the people but not the land itself. Unusually for a colony, ethnic Fijians were administered through an early version of 'indirect rule' and ethnic Fijians retained over 83 percent of land, registered to kin groups and inalienable. The colonial alliance solidified the power of coastal Christian chiefs and their kingdoms, while dispossessing other Fijian groups (Kaplan 1995; Kaplan and Kelly 1999). The colonial administration set up a sugar cane industry, but did not force ethnic Fijians to work in it.

Indians from British colonial India came to Fiji mostly as short-term indentured workers to work on British sugar plantations - part of the wide diaspora of Indian laborers in the colonial era (Tinker 1974). They called themselves Girmityas, from the indenture contracts they signed (Kelly 1988b, 1999, 2004a; Kelly and Kaplan 2008; Lal 1983; Sanadhya 1991). Their experience in colonial plantation Fiji was of an exploitative racial hierarchy. Those who chose to remain in Fiji moved away from plantations to other occupations. Indenture across empire was ended as part of Gandhi's and the Indian National Congress's first global success. Indeed, the memoir My Twenty-one Years in the Fiji Islands (Sanadhya 1991) was an important polemic in Congress's anti-indenture advocacy. Fiji's colonial sugar industry was transformed into a system of share-cropping by Indo-Fijian tenant farmers, on land rented from ethnic Fijians. Other migrants to Fiji from India included 'free' (not indentured) people, including pandits, business people, and, importantly, lawyers sent by, or with ties to, the nationalists in India (Kelly 1992).

\footnotetext{
3 The first group often call themselves 'iTaukei,' which can be translated as people of the land, or owners of the land, or the common people in relation to the chief. Throughout the colonial era and until recently, this group were called 'Fijians' - an unmarked term. In the late twentieth century there was a scholarly and activist trend to use the term 'ethnic Fijians' to create a parallel to the marked 'IndoFijians.' The Indians of Fiji were, initially, from India, and were called 'Indians' by the British. 'Indian,' as opposed to 'Fijian,' was a common usage in Fiji throughout the twentieth century, enshrined in electoral citizenship rolls, as this chapter describes. In the twentieth century, some activists and scholars used the term 'Indo-Fijian' to emphasize belonging. Thus, typically in late twentieth century Fiji, 'Fijian' meant indigene-descended Fijians, and 'Indian' or 'Indo-Fijian' meant Indian descended Fijians. In the 1980s, the Fiji Labour Party proposed using 'Fijian' to apply to all Fiji citizens. As will be discussed, the 2009 Constitution refers to all Fiji citizens as 'Fijians.'
} 
From initial Governor, Sir Arthur Gordon, onwards, colonial officials privileged ethnic Fijians, establishing an elaborate system of what in later colonies came to be called 'indirect rule.'4 And backwater Fiji officials resented colonial officials with experience in India. For example, as John Kelly has chronicled, J.R. Pearson, who had spent 30 years in India, clashed with Dr. Victor McGusty, a Fiji-trained colonial officer: Pearson operated with a social evolutionary 'progress' model, finding Indians to have 'progressed' to a point where they had a role to play in governance, both in India and in Fiji. McGusty employed fixed 'racial' categories. Insisting that he was protecting ethnic Fijians from Indian threat, he defended European pre-eminence (Kelly 1991: 140-165). In sum, throughout the colonial period, the British in Fiji regarded ethnic Fijians as their allies in the colony, especially ethnic Fijian chiefs. They regarded Indians as necessary laborers in Fiji, and denigrated their aspirations for belonging.

\section{Visions of Self-Determination in Decolonizing Fiji ${ }^{5}$}

Throughout the $20^{\text {th }}$ century, Indo-Fijians led Fiji towards independence. Indentured sugar plantation workers, their descendants, and other Indian migrants followed, and sometimes influenced, Gandhian movements to end British colonialism in India, and to establish independence throughout empire. Representation through common roll was a key goal. For example, in 1929 Vishnu Deo, a prominent Arya Samaji ${ }^{6}$ and editor of Fiji Samachar, was a successful candidate for an 'Indian' seat on the Legislative Council.

Vishnu Deo argued for a common roll voting system as a matter of equal citizenship, fairness and justice. He denied allegations that Indians sought to dominate Fiji or make it an Indian colony, noting that the majority of official members over elected members on the Legislative Council precluded Indian dominance regardless of how many Indian voters could meet the standard of the Indian electoral roll. He argued that what Indians wanted was freedom (swaraj) for India and in Fiji, "a fair field and no favour." He promised "co-

\footnotetext{
${ }^{4}$ It is important to note the diverse ways in which ethnic Fijians encountered the colonial British. Whereas an alliance of Christian, coastal chiefs, and colonial officials developed, from the 1860s on there were also dynamic anticolonial movements, often associated with the less hierarchical polities of the mountainous interior or the western side of Viti Levu island (see Kaplan 1990, 1995). Note as well the multi-ethnic appeal of the Fiji Labour Party.

5 This section draws on Kelly (1988a, 1991, 1993, 1995b, 2004b), Kaplan (1988, 1998, 2004, 2008), and on Kelly and Kaplan (2001c).

6 The Arya Samaj was founded in Bombay in 1875 by Dayanand Saraswati. It advocated reform of Hinduism by return to Vedic principles, consistent with (western) science. It was anticolonial, counterChristian, and focused on Hindu uplift. Arya Samaj missionaries were the first Hindu missionaries to Fiji (Kelly 1991: 121-139).
} 
operation" in Fiji but demanded "the full and unrestricted rights of British Citizenship." (Kelly 1991: 145)

World War II saw the end of the British Empire and the beginning of the UN era of nation-states. In Fiji, the war was a watershed, bringing into focus and contrast the differing colonial pasts and different visions of the future of ethnic Fijians and Indo-Fijians. Ethnic Fijian chiefs envisioned a system that kept them at the center of political power, and a world in which aristocratic power remained a necessary political form. Indo-Fijians, like the Indian nationalists, were more attuned to impending decolonization and democratization. Ethnic Fijians fought on behalf of the Empire during the war. Indo-Fijians followed Gandhi in refusing to fight for an imperial system that classed them as inferior. Faced with the Indo-Fijian challenge, the British claimed to represent Fijian interests, drawing upon ethnic Fijian fears of Indo-Fijian population growth, and denigrating Indian and Indo-Fijian anticolonial resistance.

At the so-called Deed of Cession debate in the Legislative Council in 1946, European members argued that the original deed of cession 'giving' Fiji to Queen Victoria and her heirs in 1874 provided that the British would preserve and protect Fijian interests. These arguments were clearly directed at quelling Indo-Fijian initiatives for greater legislative representation. Fiji Indian legislative council member A.D. Patel pointed out the irony of colonial claims to protect indigenous Fijians against foreigners and made powerful arguments against the colonial position:

"As a matter of fact," he argued, "if anything the coming of my people to this country gave the Fijians their honor, their prestige, nay indeed their very soul. Otherwise I have no hesitation in saying that the Fijians of this Colony would have met with the same fate that some other indigenous races in parts of Africa met with." (Legislative Council of Fiji 1946: 48)

In the colonial era, it had been assumed that different populations, 'races,' or 'communities' had different natures and roles to play in the colonial polity, and would each be represented separately in the governing bodies of the colony. As Fiji moved slowly towards independence, a model of representation based on 'communal' rather than 'common' electoral rolls dominated Fijis politics, with fundamental implications for the future of Fiji as a nation.

Common roll electoral systems regard all citizens as equal, with one person one vote, within a particular electoral district. Communal roll systems, on the other hand, require people to register themselves as members of particular communities, and to choose representatives of those communities. They are found primarily in former colonies that relied on 'racial' categories for political and economic structuring of the colony. Thus, until 2013 in every constitution in independent Fiji, citizens

\footnotetext{
${ }^{7}$ South Africa's recently dismantled apartheid system is another inheritor of British colonial communal political divisions.
} 
have also had to identify themselves as 'Indians,' 'Fijians,' or 'General Electors' as they carried out the task of electing representatives and shaping the nation (see The Commonwealth, n.d.; Fiji Government 2013).

Chronicling racial politics on the cusp of independence in Fiji (1969-71), a late colonial officer highlighted the implacable nature of colonial 'race' divisions. Tim Hardy (2009: 322) was a military and police specialist in the colonial service. In Fiji, he headed Special Branch, charged with identifying and dealing with threats to internal security. His sardonic and unsettling memoirs chronicle his working class origins, his distaste for empire and monarchy, and his service on behalf of a series of anti-communist colonial military and police agencies, from Africa, to Southeast Asia, to Fiji. In Fiji, Hardy belittles colonial fears of unrest in the 1960s, seeing instead the pathetic endgame jockeying of backwater colonial officials and offices attempting to maintain funding and prestige. One theme stands out from his account: the enduring colonial tendency to find threats among Indians in Fiji. Hardy finds it amusing to tell of how, as head of Special Branch, he investigated 600 dossiers of people "fingered by Special Branch as potential insurrectionists: rabble rousers, lefties, trouble-makers, agitators, racists, anti-colonialists, would be revolutionaries, and so on" (Hardy 2009: 324). He debunks the dossier of one man, a minor official of a provincial branch of the National Federation Party (the largely Indo-Fijian political party that grew out of cane farmers unions and other unions).

Nair [a pseudonym] had come to have a personal dossier only because he happened to be a minor official of the Labasa branch of the National Federation party, the Indian-run political party which, because it stood for 'liberation from colonialism', had been well and truly smeared not only by the colonial establishment but by the council of Fijian chiefs, the English-language press and the Special Branch as 'disloyal, subversive, ungrateful destructive, serving only Delhi's interests and Moscow/Peking directed.' ... I liked Mr Nair. I saw no menace in him at all. I flew back to Suva and ordered that his dossier be shredded.

I repeated the Nair test over and over again, and although I wasn't as captivated by other National Federation Party Officials as I was with Mr. Nair, the result was always the same: files into the shredder. (Hardy 2009: 325-326)

Hardy's voice is condescending. While avowing anticolonial sentiments himself, he shows little respect for the world-transforming bravery and insights that oriented Gandhian swaraj or Indo-Fijian platforms of 'liberation from colonialism.' And he didn't shred A.D. Patel's file (Hardy 2009: 327). But he confirms what archives show as well: that throughout the twentieth century, colonial Fiji ran on 'race' categories, 
in which the British privileged ethnic Fijians (especially their chiefs) and consistently denigrated Fiji Indians. ${ }^{8}$

\section{The Skewed Democracy of Independent Fiji}

The legacy of these colonial divisions was played out in independent Fiji. Repeatedly in independent Fiji, ostensible pluralism in policy coexisted with colonial continuations of ethnic Fijian paramountcy. The ceremonies of independence in 1970 dramatized these ambivalences. On the one hand, for the first time in Fiji's history, Indo-Fijians and other peoples had a major role in public ceremonies. The celebrations were intended to represent Fiji as a 'three-legged stool.' Language policy gave equal status to English, Fijian, and Fiji Hindi. But in fact, the independence ceremonies themselves, presided over by Prince Charles, gave special weight to royalty in political life, underlining the ongoing position of Fijian chiefs - a kind of authority, leadership, and appeal to tradition not open to Indo-Fijians (see Kelly and Kaplan 2001c: 121-142). The ambivalences toward pluralism seen in the independence ceremonies of 1970 were to harden into polarized political parties. In the late 1980s, multi-ethnic political party democratic victories would fall victim to ethnic Fijian military coups.

In 1970, Fiji had two major political parties which gave voice to the aspirations of Fiji's peoples for the nation-state. Because of constitutional requirements, each party had mixed 'racial' membership and fielded candidates of all three electoral categories ('Fijian,' 'Indian,' and 'General Elector'). Each at times espoused more or less pluralistic ideals. However, they swiftly became parties representing different ethnic groups. The largely Indo-Fijian National Federation Party was founded by leaders of cane growers unions and other unions in 1964, with a history of contestation against colonial policies. The largely ethnic Fijian Alliance Party, headed by ethnic Fijian chiefs, held power from 1970 to 1987.

In 1984, a new Fiji Labour Party formed to combat the 'racial' parties, with key platforms such as the designation of all Fiji citizens as 'Fijians.' Labour won the 1987 election, forming a Coalition government with the National Federation Party. Within a month, an ethnic Fijian army Colonel, Sitiveni Rabuka, led a military coup, claiming to represent ethnic Fijian interests. Rabuka became Fijis Prime Minister in elections held under the new constitution he sponsored, which was 'ratified' by Fijian high chiefs. This new constitution of 1990 simultaneously simplified and reinforced principles already at work in Fiji's Constitution at independence in 1970. Not only were the 'races' out of both balance and demographic proportion, but major offices were reserved for Fijians. ${ }^{\text {? }}$

\footnotetext{
${ }^{8}$ For further history of this late colonial period, and other examples of colonial and anticolonial discourse from the same period, see Lal (1992 and 2011), and Kelly and Kaplan (2001c).

9 See Rutz and Balkan (1992) and Rutz (1995) for delineation of plural ethnic Fijian national and
} 
However, following the establishment of this constitution, a period of debate ensued. Public discourse about the fate of the nation was largely about the ethnic Fijian polity within the polity. But simultaneously the debates and fragmentation of ethnic Fijian solidarity created opportunities for multi-ethnic, non-exclusively ethnic Fijian parties as partners. Even more importantly, concerns driven by a need to have a constitution that met recognized international standards led to the formation of the Fiji Constitution Review Commission of 1996, and then to a new constitution in 1997. While it continued some of the 1990 constitution's many concessions to ethnic Fijian custom and chiefly power (the Great Council of Chiefs were to appoint the President and Vice President, the largely ceremonial Heads of State), the new constitution altered the 'racial' composition of representation in important ways.

In a crucial expression of the voice of Fiji's citizenry, the first election under this new constitution in May of 1999 did not lead to the electoral return of coup leader Rabuka. Nor did the National Federation Party win any seats, not even its leader Jai Ram Reddy, who had become famous for his efforts to work together with coups' leader Rabuka. Rather, the multi-ethnic Labour Party, led by Mahendra Chaudhry, won an absolute majority and formed a new government in coalition with several ethnic Fijian parties. The voice of the people supported the multi-ethnic democracy envisioned in 1987 in the first Labour victory.

But one year following the election, a complicated aggregation of agents led and solidified a coup against Chaudhry's Labour Coalition government. First, George Speight, a failed businessman, led a group of military personnel and took Prime Minister Chaudhry and Coalition parliamentarians hostage. Speight claimed to act on behalf of indigenous Fijian rights. Outside analysts have noted that Speight, past head of the Fiji Hardwood and Fiji Pine commissions in the Rabuka government, had seen his carefully laid plans to sell Fiji's mahogany reserves (planted by colonial planners in the 1950s) to a US buyer overturned by the newly elected Labour coalition government. Speight's coup was overtaken and solidified by a second simultaneous coup, more from the top down, led by ethnic Fijian stalwarts. Ethnic Fijian bureaucrat Laisenia Qarase was installed as interim Prime Minister, with the support of Fiji's military forces under commander Frank Bainimarama. As head of the interim government, Qarase announced and implemented a range of programs to solidify ethnic Fijian paramountcy in the nation.

In the wake of the takeover of the nation in May and following months, there were many local takeovers of roads, power stations, tourist resorts, factories, and even police stations by ethnic Fijians asserting (as in the national takeovers) their rights as landowners and indigenes to define the nation as a whole. The interim government, headed by ethnic Fijian bureaucrat Qarase, presented its role as returning Fiji to peace, order, and 'normality.' Their interim budget and blueprint for Fiji sought to reconcile diverse ethnic Fijian claims and projects, their vision making ethnic Fijian interests the main national interests for Fiji and once again diminishing the rights

nationalist rhetorical strategies in political discourse of this coup period. 
and contributions of Indo-Fijians to the nation. Anthropologist Susanna Trnka, in her 2008 ethnography State of Suffering, has described in detail the silencing impact of the coups on many Indo-Fijians.

\section{A New Kind of Coup?}

In 2006, the military ousted Qarase and seized power. One cause may have been the Qarase government's support of a reconciliation bill that would have pardoned 2000 coup participants, including soldiers who mutinied against their superior officers. Frank Bainimarama, naval commander and head of all of Fiji's military, has also set out a series of reforms, including a common roll electoral system. When the Fiji Appeals Court found his abrogation of the constitution illegal in 2009, he dismissed and replaced the judges.
A new constitution was promulgated on 6 September 2013. It includes a bill of rights and provides for a single-chamber legislature, Parliament, with 50 members directly elected by universal adult suffrage for a term of no more than four years from its first session. All Fijian citizens from the age of 18 are entitled to vote in a single national constituency and under a system of pro- portional representation. Parliament elects a non-executive President from a field of two candidates, one nominated by the Prime Minister and one by the Leader of the Opposition. The presidential term is three years and a President can serve no more than two terms. After an election, the leader of the party with the most seats in Parliament becomes Prime Minister. The Prime Minis- ter is head of government. (The Commonwealth n.d.) ${ }^{10}$

This was the first coup that did not explicitly proclaim ethnic Fijian political paramountcy. Indeed Bainimarama has espoused a common roll for the future. Some observers have been tempted to call this the first coup to serve Indo-Fijian interests.

But the historical tactics of Indo-Fijian activism have been nonviolent: strikes, boycotts, electoral politics, and use of media to build communal solidarity and make moral arguments, in other words insistence on the truth. ${ }^{11}$ It is thus difficult to read the 2006 coup as a vehicle for Indo-Fijian hopes and aspirations in Fiji. Some Indo-Fijians and some Labour Party supporters may have hoped that the military would return the democratically elected Chaudhry government to power. But although Chaudhry was for a time in the cabinet as Finance minister, he was forced by Bainimarama to resign when he alienated foreign business investors in Fiji through

\footnotetext{
${ }^{10}$ See also Australian Broadcasting Corporation (2013), Fiji Government (2009a, 2009b, 2013), and Fraenkl, Firth and Lal (2009).

${ }_{11}$ See Kelly for an analysis of the Indo-Fijian value of shanti in relation to the ethnic Fijian value on mana Kelly (1998, 2001, 2005, 2011 and also this volume).
} 
proposing new taxes. While disavowing ethnic nationalism, Fiji's military is almost completely ethnic Fijian. The sense of political possibilities of the personnel of the coup government was surely shaped in the ethnically defined parameters of the independence political era. And the coup is a military coup. The historical tactics of Indo-Fijian activism have always been nonviolent.

The rise of political armies is surely a phenomenon connected with the nationstate, as John Kelly's chapter (this volume) discusses. But Fiji's military also evokes parallels with colonial governments. Most apparent in Fiji recently has been the impact of the military censorship of newspapers, radio, television, and internet. Claiming to seek order and normality, the military suppresses truthful accounts of Fiji and of popular will throughout the world. Early on, the newspapers were full of trivial articles from wire services or local human interest stories about dogs who took bus rides and then returned home, seemingly passive aggressive choices to fill space by deeply frustrated editors and journalists. It is hard to speculate on the motives for this particular regime's focus on media. But it seems quite similar to the colonial British insistence on rewarding loyalty and fearing what they imagine to be 'disorder and disaffection.' Yet this particular tactic seems unlikely to succeed. On the one hand, there is a deep history of anti-colonial 'vernacular' Indo-Fijian media in Fiji. And on the other hand, young people fill the internet cafes. Today's global media sources and the protean capacities of the internet reach far beyond local censoring capacities.

Are Indo-Fijians seeking self-determination by 'pessimal' belonging? ${ }^{12}$ A withdrawal strategy's limit is that it refuses - non-cooperating - to join evil. Such a tactic may not actually shape structures except by moral suasion. So, the dilemma of Indo-Fijian belonging in Fiji has continued to be the problem of self-determination, not by building the political house in which one lives, but finding oneself dwelling in a place and role constituted by others, moving into a house built by others, and for other purposes. In colonial days, Indo-Fijians refused the role of 'guest' (as some ethnic Fijians termed them) and 'working population and nothing more' (as colonial discourse would have had it) and, across their history, demanded recognition as citizens. As a tactic against violence, and a successful one (not a weapon of the weak), they embraced 'striving for minority', and indeed were the most powerful continuants of Gandhian reliance on non-violent resistance (Kelly 1995a, 1998, 2001, 2005, 2011; Kelly and Kaplan 2001b). They did not collectively protest or regret their return to minority status in the islands but, paradoxically in a democracy, hoped for better political terms as a result of minority status (Kelly 1998). In recent elections, no party commands a major political role as an explicitly Indian nationalist voice, neither as a Hindutva party (despite the rise of Modi in India) nor as a specifi-

\footnotetext{
${ }^{12}$ By pessimal, I mean an interaction strategy of minimal engagement. The term was developed by anthropologist McKim Marriott (1976) in a discussion of the social potential of different exchange and engagement strategies. Asymmetric exchanges can be what he terms "optimal" in which the exchanger emphasizes giving over receiving. Exchanges can be symmetric, some valuing many transactions in balance, others (pessimal) seeking to avoid engagement.
} 
cally Indian national congress. Might such a party arise? Perhaps not. Even when blamed for benefiting from an anti-democratic decade and consequential reforms that they did not cause, Indo-Fijians choosing to stay in Fiji strikingly sustain the path of shanti (peace), to the point of quietism. And despite emerging global hostility to migration, many still chose to leave, often citing their children's future. Most likely of all, therefore, is a continuation of the now decades-long expression of IndoFijian sentiment: self-determination by diaspora, away from Fiji.

\section{References}

Appadurai, Arjun. 1996. Modernity at Large: Cultural Dimensions of Globalization. Minneapolis: University of Minnesota Press.

Australian Broadcasting Corporation. 2013. "Fiji Government releases final version of constitution, paving the way for 2014 elections." August 22. Accessed January 22 , 2017. http://www.abc.net.au/news/2013-08-22/an-fiji-governmentreleased-final-version-of-constitution/4904020.

Benedict, Ruth. 1946. The Chrysanthemum and the Sword: Patterns of Japanese Culture. Boston: Houghton Mifflin.

Cohn, Bernard S. 1987. An Anthropologist Among the Historians and Other Essays. New Delhi: Oxford University Press.

—_. 1996. Colonialism and Its Forms of Knowledge: The British in India. Princeton: Princeton University Press.

2013. "Honor and Honors in Great Britain and India." HAU: Journal of Ethnographic Theory 3 (3): 457-67. doi:10.14318/hau3.3.031.

Cohn, Bernard S., and Teri Silvio. 2002. "Race, Gender, and Historical Narrative in the Reconstruction of a Nation: Remembering and Forgetting the American Civil War." In From the Margins: Historical Anthropology and Its Futures, edited by Brian K. Axel, 211-30. Durham: Duke University Press.

Fiji Government. 2009a. "Fiji Constitution Amendment Act 1997 Revocation Decree 2009." Republic of Fiji Islands Government Gazette 10 (1): 1. http://www.ilo.org/dyn/natlex/docs/SERIAL/86243/97189/F1075230405/ FJI86243.pdf. Accessed March 07, 2018.

—_. 2009b. "Roadmap for Democracy and Sustainable Socio-Economic Development 2010-2014: A Better Fiji for All.” Ministry of National Planning. Accessed October 08, 2017. http://www.fiji.gov.ff/getattachment/Govt--Pub lications/Peoples-Charter/RSSED.pdf.aspx.

—_. 2013. "Constitution of the Republic of Fiji." Accessed March 07, 2018. http://www.paclii.org/f/Fiji-Constitution-English-2013.pdf.

Fraenkel, Jon, Stewart Firth, and Brij V. Lal, eds. 2009. The 2006 Military Takeover in Fiji: A Coup to End All Coups? Canberra: ANU E Press. http://www.oapen. org/download?type $=$ document $\&$ docid $=458793$. 
Guha, Ranajit. 1988. "On Some Aspects of the Historiography of Colonial India." In Selected Subaltern Studies, edited by Ranajit Guha and Gayatri C. Spivak, 37-44. New York: Oxford University Press.

Hardy, Tim. 2009. The Reluctant Imperialist: An Adventurous Life in Colonial Malaya, Africa, Fiji and Hong Kong. Singapore: Marshall Cavendish Editions.

Kaplan, Martha. 1988. "The Coups in Fiji: Colonial Contradictions and the PostColonial Crisis." Critique of Anthropology 8 (3): 93-116. doi:10.1177/0308 $275 \times 8800800306$.

— 1990. "Meaning, Agency and Colonial History: Navosavakadua and the Tuka Movement in Fiji." American Ethnologist 17 (1): 3-22. doi:10.1525/ ae.1990.17.1.02a00010.

1995. Neither Cargo nor Cult: Ritual Politics and the Colonial Imagination in Fiji. Durham: Duke University Press.

—. 1998. "When 8,870-850 = 1: Discourses Against Democracy in Fiji, Past and Present." In Making Majorities: Constituting the Nation in Japan, Korea, China, Malaysia, Fiji, Turkey, and the United States, edited by Dru C. Gladney, 198-216. Stanford: Stanford University Press.

2004. "Fiji's Coups: The Politics of Representation and the Representation of Politics." In Globalization and Culture Change in the Pacific Islands, edited by Victoria Lockwood, 72-85. Upper Saddle River: Pearson Prentice Hall. . 2007. "Fijian Water in Fiji and New York: Local Politics and a Global Commodity." Cultural Anthropology 22 (4): 685-706. doi:10.1525/can.2007.22. 4.685 .

2008. "Fiji." In Nations and Nationalism: A Global Historical Overview. Volume 3 (1945-1989), edited by Guntram H. Herb and David H. Kaplan, 1313-26. Santa Barbara: Abc-Clio.

. 2011. "Alienation and Appropriation: Fijian Water and the Pacific Romance in Fiji and New York." In Changing Contexts, Shifting Meanings: Transformations of Cultural Traditions in Oceania, edited by Elfriede Hermann, 221-34. Honolulu: University of Hawai' $\mathrm{i}$ Press in Association with the Honolulu Academy of Arts.

Kaplan, Martha, and John D. Kelly. 1994. "Rethinking Resistance: Dialogics of 'Disaffection' in Colonial Fiji." American Ethnologist 21 (1): 123-51. doi: 10.1525/ae.1994.21.1.02a00070.

. 1999. "On Discourse and Power: 'Cults' and 'Orientals' in Fiji." American Ethnologist 26 (4): 843-63. doi:10.1525/ae.1999.26.4.843.

- 2017. "Constituting Common Futures: Reflecting from Singapore about Decolonisation in Fiji." In Bearing Witness: Essays in Honour of Brij V. Lal, edited by Doug Munro and Jack Corbett, 153-76: ANU Press. http://pressfiles.anu.edu.au/downloads/press/n2516/pdf/ch08.pdf.

Kelly, John D. 1988a. "Fiji Indians and Political Discourse in Fiji: From the Pacific Romance to the Coups." Journal of Historical Sociology 1 (4): 399-422. doi: 10.1111/j.1467-6443.1988.tb00013.x. 
1988b. "From Holi to Diwali in Fiji: An Essay on Ritual and History." Man 23 (1): 40-55. doi:10.2307/2803032.

—_. 1991. A Politics of Virtue: Hinduism, Sexuality, and Countercolonial Discourse in Fiji. Chicago: University of Chicago Press.

__ 1992. "Fiji Indians and 'Commoditization of Labor."' American Ethnologist 19 (1): 97-120. doi:10.1525/ae.1992.19.1.02a00060.

. 1993. "Coolie' as a Labour Commodity: Race, Sex, and European Dignity in Colonial Fiji." In "Plantations, Proletarians and Peasants in Colonial Asia." edited by E. V. Daniel, Henry Bernstein, and Tom Brass. Special issue, Journal of Peasant Studies 19 (3-4): 246-67.

__. 1995a. "Bhakti and Postcolonial Politics: Hindu Missions to Fiji." In Nation and Migration: The Politics of Space in the South Asian Diaspora, edited by Peter van der Veer, 43-72. Philadelphia: University of Pennsylvania Press. . 1995b. "Threats to Difference in Colonial Fiji." Cultural Anthropology 10 (1): 64-84. doi:10.1525/can.1995.10.1.02a00030.

. 1998. "Aspiring to Minority and Other Tactics Against Violence in Fiji." In Making Majorities : Constituting the Nation in Japan, Korea, China, Malaysia, Fiji, Turkey, and the United States, edited by Dru C. Gladney, 173-97. Stanford: Stanford University Press.

1999. "The Other Leviathans: Corporate Investment and the Construction of a Sugar Colony." In White and Deadly: Sugar and Colonialism, edited by Pal Ahluwalia, Bill Ashcroft, and Roger Knight, 95-134. Commack: Nova Science Publishers.

2001. "Fiji's Fifth Veda: Exile, Sanatan Dharm, and Countercolonial Initiatives in Diaspora." In Questioning Ramayanas: A South Asian Tradition, edited by Paula Richman, 329-51. Berkeley: University of California Press.

__ 2004a. "Gordon Was No Amateur: Imperial Legal Strategies in the Colonization of Fiji." In Law and Empire in the Pacific: Fiji and Hawai i $i$, edited by Sally E. Merry and Donald L. Brenneis, 61-100. Santa Fe: School of American Research Press.

2004b. "Jaikumari." In Bittersweet: The Indo-Fijian Experience, edited by Brij V. Lal, 47-69. Canberra: Pandanus Books.

2005. "Boycotts and Coups, Shanti and Mana in Fiji." Ethnohistory 52 (1):

13-28. doi:10.1215/00141801-52-1-13.

2011. "Shanti and Mana: The Loss and Recovery of Culture Under Postcolonial Conditions in Fiji." In Changing Contexts, Shifting Meanings: Transformations of Cultural Traditions in Oceania, edited by Elfriede Hermann, 235-49. Honolulu: University of Hawai'i Press in Association with the Honolulu Academy of Arts.

Kelly, John D., and Martha Kaplan. 1999. "Race and Rights in Fiji." In The Global Color Line: Racial and Ethnic Inequality and Struggle from a Global Perspective, edited by Pinar Batur-Vanderlippe and Joe R. Feagin, 237-57. Stanford: Jai Press. 
—. 2001a. "Nation and Decolonization." Anthropological Theory 1 (4): 419-37. doi:10.1177/14634990122228818.

—. 2001b. "Peace in Fiji." In Coup: Reflections on the Political Crisis in Fiji, edited by Brij V. Lal and Michael Pretes, 65-68. Canberra: Pandanus Books and the Research School of Pacific and Asian Studies.

—. 2001c. Represented Communities: Fiji and World Decolonization. Chicago: University of Chicago Press.

—. 2004. "'My Ambition Is Much Higher Than Independence': US Power, the UN World, the Nation-State, and Their Critics." In Decolonization: Perspectives from Now and Then, edited by Prasenjit Duara, 131-51. London: Routledge.

—. 2007. "Diaspora and Swaraj, Swaraj and Diaspora." In From the Colonial to the Postcolonial: India and Pakistan in Transition, edited by Dipesh Chakrabarty, Rochona Majumdar, and Andrew Sartori, 311-31. Oxford: Oxford University Press.

—. 2008. "Legal Fictions After Empire." In The State of Sovereignty: Territories, Laws, Populations, edited by Douglas R. Howland and Louise White, 169195. Bloomington: Indiana University Press.

Lal, Brij V. 1983. Girmityas: The Origins of the Fiji Indians. Canberra: Journal of Pacific History.

- 1988. Power and Prejudice: The Making of the Fiji Crisis. Wellington: New Zealand Institute of International Affairs.

— 1992. Broken Waves: A History of the Fiji Islands in the Twentieth Century. Honolulu: University of Hawai'i Press.

- (1997) 2011a. A Vision for Change: AD Patel and the Politics of Fiji. Canberra: ANU E Press. http://press-files.anu.edu.au/downloads/press/p151821/ pdf/book.pdf?referer $=458$.

—., ed. 2011 b. A Vision for Change: Speeches and Writings of AD Patel, 19291969. Canberra: ANU Press. http://www.oapen.org/download?type=documen t\&docid $=459773$.

Legislative Council of Fiji. 1946. Extract from Debates of July Session 1946. Suva: Government Printer.

Marriott, McKim. 1976. "Hindu Transactions: Diversity without Dualism.” In Transaction and Meaning: Directions in the Anthropology of Exchange and Symbolic Behavior, edited by Bruce Kapferer, 109-42. Philadelphia: Institute for the Study of Human Issues.

Rittel, Horst W. J., and Melvin M. Webber. 1973. "Dilemmas in a General Theory of Planning." Policy Sciences 4 (2): 155-69. doi:10.1007/BF01405730.

Rutz, Henry J. 1995. "Occupying the Headwaters of Tradition: Rhetorical Strategies of Nation Making in Fiji." In Nation Making: Emergent Identities in Postcolonial Melanesia, edited by Robert J. Foster, 72-93. Ann Arbor: University of Michigan Press. 
Rutz, Henry J., and Erol M. Balkan. 1992. "Never on Sunday: Time-Discipline and Fijian Nationalism." In The Politics of Time, edited by Henry J. Rutz, 62-85. Washington, D.C. American Anthropological Association.

Sahlins, Marshall D. 1978. Culture and Practical Reason. Chicago: University of Chicago Press.

—_ 1985. Islands of History. Chicago: University of Chicago Press. 2005. Culture in Practice: Selected Essays. New York: Zone Books.

Sanadhya, Totaram. 1991. My Twenty-One Years in the Fiji Islands. Edited by John D. Kelly. Suva: The Fiji Museum. Translated from Hindi by John D. Kelly and Uttra Singh. Introduction and Research Appendices by John D. Kelly.

Tambiah, Stanley J. 1996. Leveling Crowds: Ethnonationalist Conflicts and Collective Violence in South Asia. Berkeley: University of California Press.

The Commonwealth. n.d. "Fiji : Constitution and Politics." Accessed January 22, 2017. http://thecommonwealth.org/our-member-countries/fiji/constitutionpolitics\#sthash.ul82GCbj.dpuf.

Tinker, Hugh. 1974. A New System of Slavery: The Export of Indian Labour Overseas 1830-1920. London: Published for the Institute of Race Relations by Oxford University Press.

Trnka, Susanna. 2008. State of Suffering: Political Violence and Community Survival in Fiji. Ithaca: Cornell University Press. 